\section{Attitudinal meanings of Judgement in the inaugural addresses by the US presidents during the Cold War}

\author{
Shutang Zhang \\ School of Foreign Languages, University \\ of Jinan, Shandong Province, China
}

\begin{abstract}
The Appraisal Theory intends to study how the stance, the opinion and the attitude of language users are realized in discourses. This paper discusses the attitudinal meanings of Judgement in the inaugural addresses by the US presidents during the Cold War under the framework laid down by Martin and White. It has been found that the attitudinal meanings of Judgement account for the most part of all the attitudinal meanings in all the 11 addresses, and that the positive Judgements are foregrounded by its high percentage in all the attitudinal meanings of Judgement. The features in the use of attitudinal meanings of Judgement serve the purpose of the presidential inaugural addresses very well, i.e. to convey a new administration's commitment to their future work and to win support from the audience.
\end{abstract}

\section{Introduction}

The Appraisal Theory, as the further development of interpersonal meaning research within the framework of Systemic Functional Grammar, explores the interlocutors' stance towards both the material they present and the rivals with whom they communicate. It focuses on the attitude reflected in language use. The system of attitude involves three semantic regions, i.e. emotions, ethics and esthetics. ${ }^{1}$ These three subsystems are renamed Affect, Judgement and Appreciation.

The attitude of the US presidents towards the world around them is still of lasting interest for people worldwide. This paper intends to focus on the attitudinal meanings of Judgement in the inaugural addresses of the US presidents during the Cold War (1947-1991) and to explore detailed features in the use of Judgement resources.

\section{Studies in attitude and inaugural addresses}

Attitude has been studied under many other titles, such as evaluation, ${ }^{2}$ stance,${ }^{3}$ evidentiality, ${ }^{4}$ and hedging. ${ }^{5,6}$ Hunston and Thompson ${ }^{7}$ make a detailed summary of the studies in attitudes, and make a distinction between the opinions about entities and propositions in the world. Opinions about entities in the world are attitudinal involving positive and negative feelings; opinions about propositions are epistemic involving degree of certainty. They point out that the former tends to take lexical forms and the latter grammatical forms. We also find a similar distinction in Ochs and Schiefflen, ${ }^{2}$ Biber and Finnegan, ${ }^{4}$ Bybee and Fleischman, ${ }^{3}$ and Conrad and Biber, ${ }^{8}$ among others.

The Appraisal Theory outlines a more comprehensive summary of the attitude system that extends the traditional study of emotions to attitude, including Affect, Judgement and Appreciation, together with two other systems, i.e. Engagement and Graduation, with the former similar to evidentiality and the latter similar to hedging. All three systems make up the appraisal system in a language.

The study of political public speech from the rhetorical perspective has a long history. Chilton and Schaffner ${ }^{9}$ point out that rhetoric is the art of verbal persuasion. The Ancient Greeks and Romans regarded the study of rhetoric as a sort of political science. As rhetoric was studied mainly for political purposes, its study was closely related to that of political speaking. The study of rhetoric can be traced back as far as around $480 \mathrm{BC}$ when the Greek philosopher Corax began teaching the art of public speaking. He defined some of the basic structures, including the organizational structures of a speech and the elements of persuasion. ${ }^{10} \mathrm{He}$ laid the groundwork for scholars like Socrates, Plato, and the most important contributor to political speech, Aristotle. However, the study of inaugural addresses by the US presidents during the Cold War has received little attention in the field of discourse analysis. A few studies of the inaugural addresses have been carried out in the form of rhetorical analysis for speech writing. The analysis of the attitudinal meanings of Judgement in the inaugural address by the US presidents during the Cold War will provide an insight into the nature of language use in political speeches.

\section{The framework of attitudinal meaning of Judgement}

The Appraisal Theory divides the linguistic resources for attitudes into three interacting domains: Attitude (resources concerned with feelings), Engagement (resources dealing with sourcing attitudes), Graduation (resources attending to grading attitudes), with Attitude at the center of the whole appraisal system.
Correspondence: Shutang Zhang, School of Foreign Languages, University of Jinan, Shandong Province, China, 250022.

E-mail: sfl_zhangst@ujn.edu.cn

Key words: judgement, inaugural addresses, US presidents, Cold War.

Acknowledgements: the paper was presented during the 2011 Shanghai International Conference on Social Science (SICSS 2011).

Received for publication: 20 September 2011. Revision received: 7 April 2012.

Accepted for publication: 21 may 2012.

This work is licensed under a Creative Commons Attribution 3.0 License (by-nc 3.0).

@C Copyright S. Zhang, 2012

Licensee PAGEPress, Italy

Antiqua 2012; 2:e2

doi:10.4081/antiqua.2012.e2

Attitude is itself divided into three sub-systems: i) affect: the characterization of phenomena by reference to emotion; ii) judgement: the evaluation of human behavior with respect to social norms; iii) appreciation: the evaluation of objects and products (rather than human behavior) by reference to esthetic principles and other systems of social values.

The present paper will focus on the framework of the Judgement system. Judgement refers to the attitudinal meanings that construe our attitudes to people and the way they behave: their character (how they measure up). In other words, Judgement serves to evaluate human behavior positively or negatively by reference to a set of institutionalized norms. In general terms, Judgements can be divided into two types: those dealing with social esteem and those oriented to social sanction. Judgements of social esteem involve evaluations under which the person judged would be lowered or raised in the esteem of their community, but which do not have legal or moral implications. Thus, negative values of social esteem will be seen as dysfunctional or inappropriate or to be discouraged, but they will not be regarded as sins or crimes. Judgements of social esteem can be divided into the three subcategories: normality (how unusual someone is, how customary their behaviour is), capacity (how capable someone is) and tenacity (how resolute someone is; how dependable someone is; how well they are disposed emotionally). Judgements of social sanction refer to the evaluations of human behavior by reference to a certain set of rules or regulations, more or less explicitly codified by the culture. So Judgements of social sanction turn on questions of legality and morality. 
Judgements of social sanction can be divided into the two subcategories: veracity (how truthful someone is) and propriety (how ethical someone is). ${ }^{1}$ Ways in which Judgements are expressed are presented in Table 1.

So, under Judgement we may assess behavior as moral or immoral, as legal or illegal, as socially acceptable or unacceptable, as normal or abnormal, and so on. White ${ }^{11}$ illustrates the differences between social esteem and social sanction: If you breach social sanction, you may well need a lawyer or a confessor, but if you breach social esteem, you may just need to try harder or to practice more or to consult a therapist or possibly a self-help book.

The canonical grammatical expression of attitudinal meaning of Judgement is adjectival. Judgement can be distinguished by a relational attributive process ascribing an attitude to some person's behavior: it was Judgement for person/of person to do that OR (for person) to do that was judgement. For example, it was silly of/for them to do that; (For them) to do that was silly. ${ }^{1}$

\section{The analysis of the inaugural addresses}

The 11 presidential inaugural addresses during the Cold War have been chosen as the corpus from which to find the features of the attitudinal meanings.

\section{Definition of the corpus}

The Cold War in the present paper refers to the state of political tension and military rivalry between nations that stops short of full-scale war, especially that which existed between the United States and the Soviet Union following World War II from 1947-1991 (http///www.thefreedictionary.com/cold+war). During this period, 9 presidents made 13 inaugural addresses, with Dwight D. Eisenhower, Lyndon B. Johnson, Richard M. Nixon, and Ronald Reagan making 2 inaugural addresses each. Only 11 of the 13 inaugural addresses were delivered at an interval of four years by 8 presidents and these have been chosen as the data for the present study. The other 2 inaugural addresses in this period, were the first inaugural speech by President Lyndon B. Johnson, who took the presidential oath after the assassination of President John. F. Kennedy in 1963, and the inaugural address by President Gerald Ford, who took the presidential oath after the resignation of President Richard in 1974. These have not been taken into consideration because they were not delivered at the traditional four-year interval. These 11 inaugural addresses present a total of 22174 words and these will be analyzed.

\section{Annotating the attitudinal meanings of Judgement}

The attitudinal meaning of the 11 inaugural addresses during the Cold War was annotated according to the following procedures: i) identifying the appraising items of the attitudinal meanings of Judgement from the other two kinds of attitudinal meanings, i.e. Affect and Appreciation; ii) annotating the specific type of attitudinal meanings of Judgement in terms of its subcategories, i.e. normality, capacity, tenacity, veracity, propriety; iii) annotating whether attitudinal meaning of Judgement is positive or negative; iv) annotating the source of the attitude (appraiser or emoter) and the target of appraisal (the appraised items or triggers) of the attitudinal meanings of Judgement; v) collecting statistical data about the number of the attitudinal meanings of Judgement and their detailed classification in terms of the subsystems of Judgement. The annotation process is shown in Table 2.

Table 1. The system of Judgement.

\begin{tabular}{|c|c|c|}
\hline Social esteem & Positive & Negative \\
\hline $\begin{array}{l}\text { Normality } \\
\text { How special? }\end{array}$ & Lucky, normal fashionable, ... & Unlucky, odd, dated, ... \\
\hline $\begin{array}{l}\text { Capacity } \\
\text { How capable? }\end{array}$ & Witty, literate, competent, & Dull, illiterate, incompetent, \\
\hline $\begin{array}{l}\text { Tenacity } \\
\text { How dependable? }\end{array}$ & Plucky, brave, hero & Timid, cowardly, gutless, ... \\
\hline Social sanction & Positive & Negative \\
\hline $\begin{array}{l}\text { Veracity [truth] } \\
\text { How honest? }\end{array}$ & Truthful, honest, credible, ... & Dishonest, deceitful, lying, ... \\
\hline $\begin{array}{l}\text { Propriety [ethics] } \\
\text { How far beyond reproach? }\end{array}$ & Good, moral, fair, just, ... & Bad, immoral, unfair, unjust, ... \\
\hline
\end{tabular}

Table 2. Classification of the Judgements in the analysis.

\begin{tabular}{ccccc} 
& Appraising items & Appraiser/emoter & Judgement & Appraised/trigger \\
Para.1 & With humility & Speaker & + Ten & I \\
Para.1 & With a deep resolve & Speaker & + Ten & I \\
\hline Para.2 & Work together & Speaker & + Cap & We \\
Para.7 & Have a right to equal justice & Speaker & T+prop & All men \\
\hline
\end{tabular}

Nor, normality; cap, capability; ten, tenacity; ver, veracity; pro, propriety; T, Token; +, positive; -, negative.

Table 3. The number and percentage of the three kinds of attitudes.

\begin{tabular}{lccccccc}
\hline Year & \multicolumn{2}{c}{ Affect } & \multicolumn{2}{c}{ Judgement } & \multicolumn{2}{c}{ Appreciation } & Total \\
1949 & 51 & $21 \%{ }^{*}$ & 118 & $49 \%$ & 73 & $30 \%$ & 242 \\
1953 & 44 & $20 \%$ & 99 & $46 \%$ & 73 & $34 \%$ & 216 \\
\hline 1957 & 57 & $31 \%$ & 81 & $44 \%$ & 46 & $25 \%$ & 184 \\
1961 & 43 & $32 \%$ & 65 & $50 \%$ & 25 & $18 \%$ & 133 \\
\hline 1965 & 31 & $28 \%$ & 51 & $45 \%$ & 30 & $27 \%$ & 112 \\
1969 & 70 & $36 \%$ & 83 & $44 \%$ & 38 & $20 \%$ & 191 \\
\hline 1973 & 48 & $32 \%$ & 67 & $46 \%$ & 33 & $22 \%$ & 148 \\
1977 & 24 & $23 \%$ & 59 & $58 \%$ & 20 & $19 \%$ & 103 \\
\hline 1981 & 37 & $24 \%$ & 92 & $59 \%$ & 26 & $17 \%$ & 155 \\
1985 & 45 & $25 \%$ & 91 & $51 \%$ & 44 & $24 \%$ & 179 \\
\hline 1989 & 42 & $27 \%$ & 71 & $46 \%$ & 41 & $27 \%$ & 154 \\
Total & 492 & $27 \%$ & 876 & $48 \%$ & 449 & $25 \%$ & 181 \\
\hline
\end{tabular}

*21\% refers to the percentage of the number of affects in the speech out of all the attitudinal meanings of Judgement in the most left column. This also applies to other categories in the present paper. 


\section{Data from the analysis of 11} inaugural addresses by the US presidents during the Cold War

All the attitudinal meanings, including Affect, Judgement and Appreciation, are annotated in order to achieve a better understanding of Judgement. Details of all the attitudinal meanings are presented in Tables 3 and 4.

The distribution of positive and negative Judgements is summarized in Table 5 .

\section{Features of attitudinal meanings of Judgement in the 11 presidential addresses during the Cold War}

Attitudinal meanings of Judgement are foregrounded in the three attitudinal meanings. All the attitudinal meanings of Judgement in the 11 presidential inaugural addresses during the Cold War account for $48 \%$ in all the attitudinal meanings, and the respective percentage of Judgement in the 11 addresses ranges from $44 \%$ to $59 \%$. From the data above, it can be concluded that making Judgements was an essential part of the presidential inaugural addresses during the Cold War.

Most of the Judgements are positive. As shown in Table 5, among all the attitudinal meanings, the positive Judgements account for $83.7 \%$, and the most frequently appraised entity is $u s$ (referring to the new administration, or the US nation as a whole). Positive Judgements are applied to evaluate the speaker as a president, the government, and the US people as a nation, and they are evaluated most in terms of propriety, capability and tenacity, which account for $41.7 \%, 38.8 \%$ and $16.3 \%$ respectively. So we can see that the foregrounded Judgements among all the attitudinal meanings and the foregrounded positive Judgements are mostly used to appraise $u s$ (referring to the new administration with the president at its head, or the US nation as a whole). In other words, the speakers evaluate American people or the US positively for their actions in term of capability, tenacity and propriety. With the positive Judgements in each speech, the speaker convinces the audience of the abilities and tenacity that the US and her people and government possess, and justifies the actions or behaviors that have been taken or will be taken by the nation and the government. With these positive Judgements, the speakers show the propriety of the forthcoming policies and actions to be taken by the new administration, assuring the audience of the capability of the new administration, so as to unite the whole nation after the competitiveness of the election campaign. Of course, these positive Judgements serve to convince the audience of the capability of the speaker, the president as the head of the national government of the United States of America.

Although negative Judgements only account for $16.3 \%$ out of all the Judgements, they also play important roles. Negative Judgements are also employed to evaluate we/us (referring to the nation, the people and the government of the US), not for denigration but for pointing out the existing weakness or difficulties and the lessons gained from the past and history. Some examples will clearly illustrate this (Appendix I and II).

i) Our problems are large; token of negative Judgements of we/us (referring to the nation, the people and the government of the US) in terms of capability. (Para. 26, Bush, 1989).

ii) There is little we can do: token of negative Judgements of we/us (referring to the nation, the people and the government of

Table 4. The number and percentage of attitudinal meanings of Judgement.

\begin{tabular}{|c|c|c|c|c|c|c|}
\hline Jud/Year & Nor & Cap & Ten & Ver & Pro & Total \\
\hline 1949 & $\begin{array}{c}1 \\
1 \%\end{array}$ & $\begin{array}{c}53 \\
45 \%\end{array}$ & $\begin{array}{c}20 \\
17 \%\end{array}$ & $\begin{array}{c}1 \\
1 \%\end{array}$ & $\begin{array}{c}43 \\
36 \%\end{array}$ & 118 \\
\hline 1953 & $\begin{array}{c}3 \\
3 \%\end{array}$ & $\begin{array}{c}39 \\
39 \%\end{array}$ & $\begin{array}{c}13 \\
13 \%\end{array}$ & $\begin{array}{c}1 \\
1 \%\end{array}$ & $\begin{array}{c}43 \\
43 \%\end{array}$ & 99 \\
\hline 1957 & $\begin{array}{c}2 \\
3 \%\end{array}$ & $\begin{array}{c}23 \\
28 \%\end{array}$ & $\begin{array}{c}11 \\
14 \%\end{array}$ & $\begin{array}{c}1 \\
1 \%\end{array}$ & $\begin{array}{c}44 \\
54 \%\end{array}$ & 81 \\
\hline 1961 & $\begin{array}{c}2 \\
3 \%\end{array}$ & $\begin{array}{c}17 \\
26 \% \\
\end{array}$ & $\begin{array}{c}16 \\
25 \% \\
\end{array}$ & $\begin{array}{l}0 \\
0\end{array}$ & $\begin{array}{c}30 \\
46 \% \\
\end{array}$ & 65 \\
\hline 1965 & $\begin{array}{c}1 \\
1 \%\end{array}$ & $\begin{array}{c}21 \\
41 \%\end{array}$ & $\begin{array}{c}5 \\
9 \%\end{array}$ & $\begin{array}{l}0 \\
0\end{array}$ & $\begin{array}{c}25 \\
49 \%\end{array}$ & 51 \\
\hline 1969 & $\begin{array}{c}4 \\
5 \%\end{array}$ & $\begin{array}{c}35 \\
42 \%\end{array}$ & $\begin{array}{c}14 \\
17 \%\end{array}$ & $\begin{array}{c}1 \\
1 \%\end{array}$ & $\begin{array}{c}28 \\
35 \%\end{array}$ & 83 \\
\hline 1973 & $\begin{array}{l}0 \\
0\end{array}$ & $\begin{array}{c}17 \\
26 \%\end{array}$ & $\begin{array}{c}11 \\
16 \%\end{array}$ & $\begin{array}{l}0 \\
0\end{array}$ & $\begin{array}{c}39 \\
58 \%\end{array}$ & 67 \\
\hline 1977 & $\begin{array}{l}0 \\
0\end{array}$ & $\begin{array}{c}31 \\
52 \%\end{array}$ & $\begin{array}{c}5 \\
8 \%\end{array}$ & $\begin{array}{c}1 \\
2 \%\end{array}$ & $\begin{array}{c}23 \\
38 \%\end{array}$ & 59 \\
\hline 1981 & $\begin{array}{c}6 \\
6 \%\end{array}$ & $\begin{array}{c}30 \\
33 \%\end{array}$ & $\begin{array}{c}22 \\
24 \%\end{array}$ & $\begin{array}{l}0 \\
0\end{array}$ & $\begin{array}{c}34 \\
37 \%\end{array}$ & 92 \\
\hline 1985 & $\begin{array}{l}0 \\
0\end{array}$ & $\begin{array}{c}46 \\
51 \%\end{array}$ & $\begin{array}{c}15 \\
16 \%\end{array}$ & $\begin{array}{l}0 \\
0\end{array}$ & $\begin{array}{c}30 \\
33 \%\end{array}$ & 91 \\
\hline 1989 & $\begin{array}{c}3 \\
6 \%\end{array}$ & $\begin{array}{c}28 \\
39 \%\end{array}$ & $\begin{array}{c}11 \\
16 \%\end{array}$ & $\begin{array}{c}1 \\
1 \%\end{array}$ & $\begin{array}{c}26 \\
38 \%\end{array}$ & 71 \\
\hline Total & $\begin{array}{c}22 \\
2.5 \%\end{array}$ & $\begin{array}{c}340 \\
38.8 \%\end{array}$ & $\begin{array}{c}143 \\
16.3 \% \\
\end{array}$ & $\begin{array}{c}6 \\
0.7 \% \\
\end{array}$ & $\begin{array}{c}365 \\
41.7 \%\end{array}$ & 876 \\
\hline
\end{tabular}

Jud, judgement; Nor, normality; cap, capability; ten, tenacity; ver, veracity; pro, propriety.

Table 5. The number and percentage of positive and negative Judgement.

\begin{tabular}{llllll} 
Year & \multicolumn{2}{l}{ Positive Judgement +} & \multicolumn{2}{c}{ Negative Judgement - } & Total \\
1949 & 94 & $79.7 \%$ & 24 & $20.3 \%$ & 118 \\
1953 & 82 & $82.8 \%$ & 17 & $17.2 \%$ & 99 \\
\hline 1957 & 59 & $72.8 \%$ & 22 & $27.2 \%$ & 81 \\
1961 & 53 & $81.5 \%$ & 12 & $18.5 \%$ & 65 \\
\hline 1965 & 42 & $82.4 \%$ & 9 & $17.6 \%$ & 51 \\
1969 & 70 & $84.3 \%$ & 13 & $16.7 \%$ & 83 \\
\hline 1973 & 62 & $96.9 \%$ & 5 & $3.1 \%$ & 67 \\
1977 & 55 & $93.2 \%$ & 4 & $6.8 \%$ & 59 \\
\hline 1981 & 82 & $89.1 \%$ & 10 & $10.9 \%$ & 92 \\
1985 & 76 & $83.5 \%$ & 15 & $16.5 \%$ & 91 \\
\hline 1989 & 58 & $81.7 \%$ & 13 & $18.3 \%$ & 71 \\
Total & 733 & $83.7 \%$ & 143 & $16.3 \%$ & 876 \\
\hline
\end{tabular}


the US) in terms of capability. (Para. 6, Kennedy, 1961).

iii) Embattled: negative judgements of we/us (referring to the nation, the people and the government of the US) in terms of normality. (Para. 22, Kennedy, 1961).

iv) Forgotten in abundance what we learned in hardship: token of negative Judgements of we/us (referring to the nation, the people and the government of the US) in terms of propriety. (Para. 27, Johnson, 1965).

v) Our weaknesses: negative Judgements of we/us (referring to the nation, the people and the government of the US) in terms of capability. (Para. 16, Nixon, 1969).

The Soviet Union and communism are indispensable content in the US presidential inaugural addresses during the Cold War, and are evaluated directly and indirectly. As far as Judgement is concerned, the Soviet Union and communism are negatively evaluated, especially in terms of propriety. This is clearly illustrated in the following examples: i) A threat to the effort: negative Judgements of actions resulting from the Communist philosophy in terms of propriety. (Para. 22, Truman, 1949). ii) Know no god but force, no devotion but its use: token of negative Judgements of the enemies of this faith (The Soviet Union and communism) in terms of propriety. (Para. 20, Eisenhower, 1953). iii) Dark in purpose: negative Judgements of the design of that power (the Soviet Union and communism) in terms of propriety. (Para. 15, Eisenhower, 1957).

\section{Conclusions}

Attitudinal meanings of Judgement are foregrounded in all the inaugural speeches during the Cold War, which account for more than $44 \%$ of all the attitudinal meanings in every speech, and us (referring to the nation, the people and the government of the US) is typically appraised, especially in terms of propriety and capability. The Soviet Union and communism are evaluated negatively in all the addresses in which they are mentioned. These features of the use of the attitudinal meanings of Judgement serve the interpersonal function of presidential inaugural addresses very well, i.e. to state implicitly or explicitly the speaker's Judgements to the audience so as to influence and persuade them.

\section{References}

1. Martin JR. Writing history: construing time and value in discourses of the past. In: Colombi C, Schleppergrell M, (eds). Developing advanced literacy in first and second languages. Mahwah, NJ: Erlbaum; 2002. pp 87-118.

2. Ochs E, Schiefflen B. Language has a heart. (Special Issue on The Pragmatics of Affect). Text 9.1 1989:7-25.
3. Bybee J, Fleischman S. Modality in grammar and discourse. Amsterdam: Benjamins; 1995.

4. Biber D, Finnegan E. Styles of stance in English: lexical and grammatical marking of evidentiality and affect. (Special Issue on The Pragmatics of Affect). Text 9.1 1989:93-124.

5. Lakoff G. Hedging: a study in meaning criteria and the logic of fuzzy concepts. Proc Chicago Linguist Soc 1972;8:183-228.

6. Brown P, Levinson S. Politeness: some universals in language usage. Cambridge: Cambridge University Press; 1987.

7. Hunston S, Thompson G, (eds). Evaluation in text: authorial stance and the construction of discourse. Oxford: Oxford University Press; 2000.

8. Conrad S, Biber D. Adverbial marking of stance in speech and writing. H\&T 2000; 56-73.

9. Chilton P, Schaffner C. Genres and registers of discourse. In: Van Dijk (ed.). Discourse as Social Interaction. London: SAGE Publications Ltd.; 1997. pp 206-231.

10. Hasling J. The Audience, the message, and the speaker. New York: McGraw-Hill, Inc.; 1993.

11. White PRR. Appraisal outline (an introduction tour through appraisal theory); 2001. Available from: www.grammatics.com/ appraisal 